\title{
Study of foliar epidermal anatomy of four pistachio rootstocks under water stress
}

\author{
Estudio de la anatomía foliar epidermal de cuatro rizomas de pistacho \\ bajo estrés hídrico
}

\author{
Kazem Arzani $^{1 *}$, Mostafa Ghasemi $^{1}$, Abbas Yadollahi $^{1}$, Hossein Hokmabadi $^{2}$
}

\begin{abstract}
Pistachio is one of the most important horticultural crops grown in Iran. In this study epidermal cells in leaves of four Pistachio rootstocks (Pistacia vera, cv. Badami Zarand, Sarakhs, Ghazvini and Pistacia mutica) grown under three irrigation levels (100\%, $65 \%$ and $30 \% \mathrm{ET}_{\mathrm{c}}$ ) were evaluated. Stomata density and stomata dimension (length and width) were detemined by light microscope and scanning electron microscope (SEM), respectively. The results showed that irrigation, rootstock and their interaction had significant effects on stomata density and stomata length. Effect of irrigation on stomata width was significant while rootstock and interaction of irrigation and rootstock had no significant effects on stomata width. The highest stomata density and the lowest stomtal length and width were obtained in severe water stress. The highest and the lowest stomata density on the abaxial surface was belonged to $P$. mutica $\left(530.30 \mathrm{no} / \mathrm{mm}^{2}\right)$ and $P$. vera 'Ghazvini $\left(404.04 \mathrm{no} / \mathrm{mm}^{2}\right)$, respectively. The rootstocks $P$. $m u t i c a$ and $P$. vera 'Ghazvini' had the highest and $P$. vera 'Badami' and $P$. vera 'Sarakhs' the lowest stomata length of stomata. The rootstocks showed no significant difference in case of stomata width. The shape of epidermal cells also was different among studied rootstocks. All rootstocks had Anomocytic stomata. Among studied rootstocks only P.mutica had trichomes on abaxial surface. Presence of trichomes in this rootstock is a characteristic distinguishable. It was found a negative correlation $(-0.432)$ between stomata density and stomata width $(\mathrm{P} \leq 0.01)$. There were not found correlation between stomata density and stomata length, while in severe treatment of water stress was observed significant negative correlation between stomata density and stomata length $(-.0 .675)$ at $P \leq 0.05$. $P$. vera 'Ghazvini had the lowest number of stomata but wider stomata. Anatomical differerences may be useful as an initial screening method for classifying pistachio rootstocks of drought resistance.
\end{abstract}

Key words: epidermal cells, pistachio, anatomy, water stress.

\section{RESUMEN}

El pistacho es uno de los cultivos hortícolas más importantes producidos en Irán. En este estudio fueron evaluadas las células epidérmicas de las hojas de cuatro portainjertos de pistacho (Pistacia vera, cv. Badami Zarand, Sarakhs, Ghazvini y Pistacia mutica) obtenidas bajo tres niveles de riego $\left(100 \%, 65 \%\right.$ y $\left.30 \% E_{c}\right)$. La densidad y dimensión (longitud y ancho) de los estomas se determinaron por microscopio de luz y microscopio electrónico de barrido (SEM), respectivamente. Los resultados sugieren que el riego, los portainjertos y su interacción tienen efectos significativos sobre la densidad y la longitud de los estomas. El efecto del riego en el ancho de los estomas fue significativo. El portainjerto y la interacción de riego no tuvo efectos significativos sobre el ancho de los estomas. La mayor densidad de estomas y la menor longitud y ancho estomatal se obtuvo al aumentar el estrés hídrico. La mayor y menor densidad de estomas en la superficie abaxial se obtuvo en P. mutica $\left(530.30 \mathrm{no} / \mathrm{mm}^{2}\right)$ y P. vera "Ghazvini" (404.04 no/mm²), respectivamente. En los portainjertos P. mutica y P. vera "Ghazvini" se obtuvo el mayor largo de estomas, en tanto la menor longitud se observó en P. vera "Badami" y P. vera "Sarakhs". No hubo diferencia significativa en el ancho de estomas en los patrones evaluados. La forma de las células epidérmicas fue diferente entre los portainjertos estudiados. En todos los patrones se observó estomas anomocíticos. Entre los portainjertos estudiados sólo P. mutica tuvo tricomas en la superficie abaxial, donde la presencia de los tricomas en este patrón es una característica distinguible. Se encontró una correlación negativa $(-0,432)$ entre la densidad y ancho de estomas $(P \leq 0.01)$. No se encontró correlación entre la densidad y longitud de estomas, mientras que en el tratamiento del estrés hídrico severo se observó una correlación negativa significativa entre la densidad y longitud (-0.675) en $P \leq 0,05$. En P. vera "Ghazvini" se observó menos estomas, pero de mayor ancho. Los resultados sugieren que las diferencias anatómicas pueden ser útiles como un método de cribado inicial para la clasificación de patrones de pistacho con resistencia a la sequía.

Palabras clave: células epidérmicas, pistacho, anatomía, déficit hídrico.

\footnotetext{
1 Department of Horticultural Science. Tarbiat Modares University (TMU), PO Box 14115-336 Tehran, Iran.

* Corresponding author E-mail: arzani_k@modares.ac.ir

2 Iran's Pistachio Research institute (IPRI).
}

Fecha de Recepción: 05 Diciembre, 2012.

Fecha de Aceptación: 04 Enero, 2013. 


\section{Introduction}

Most plants grown in mediterranean climates are subjected to heat and drought stresses during the summer, therefore most of them have morphological, anatomical, physiological, biochemical and metabolic mechanisms in order to adaption and survive (Belhadj et al., 2007, Bosabalidis and Kofidis, 2002, Elfadl and Luukkanen, 2006). Epidermis tissues have three types of main cells include epidermal cells, guard cells with their subsidiary cells and trichomes or leaf hairs (Munir et al., 2011). In most species, frequency of stomata in the lower epidermis are more than the upper epidermis (Muradoglu and Gundogdu, 2011). Traits of leaf epidermal tissue such as stomata size and shape as well as form of trichomes are valuable in taxonomy and identification of plant genera and species (Munir et al., 2011, Scatena et al., 2005; Dickison, 2000). Anatomical traits such as high stomatal density, a reduction of stomata size and deeply developed stomata can be used for identification of xerophytic plants (Martins and Zieri, 2003, Belhadj et al., 2007). Stomata characteristics such as frequency and dimensions are greatly affected by type of species and environmental factors (Munir et al., 2011, XueJun and XinShi, 2000). Environmental stresses such as water stress most effects on leaf traits (XueJun and XinShi, 2000). In environments with low CO2 concentration, plants have higher stomatal index but in $\mathrm{CO} 2$ rich environment (mostly along road sides) they have lower stomatal index (Munir et al., 2011). Belhadj et al. (2011) reported stomata density of $P$. atlantica populations decreased with increase of altitude. Microscopic examinations of stomata allow to detect quantitative and qualitative differences among the studied plants. EL-Oqlah (1996) reported that anatomical differences may be used as important taxonomic traits for discriminate between the highly similar species of Pistacia. The genus Pistachio belonged to family Anacardiaceae is a xerophytes plant (Belhadj, 2007) and Iran is one of its origins and diversity centers. Few anatomical studies have published on Pistacia rootstocks, therefore in this study, leaf epidermal cells of four Pistachio rootstocks grown under three irrigation levels were evaluated. These anatomical variabilities can be used in genetic improvement programs.

\section{Materials and Methods}

In this study, we investigated foliar epidermal anatomy of four pistachio rootstocks grown under three irrigation levels (100\% ETc, 65\% ETc and 30\% ETc). Irrigation treatments were applied on 4 months old seedlings grown in greenhouse. Sixty days after application treatments, foliar epidermal anatomy of seedlings evaluated. Rootstocks were include four pistachio rootstocks (Pistacia mutica and 3 variety of Pistacia vera Badami, Sarakhs and Ghazvini) that are common rootstocks of $P$. vera in Iran. Seeds of rootstocks were provided by the Iran's Pistachio Research institute, Rafsanjan, Iran. Determination of stomata density on lower surface of leaf (abaxial surface) was carried out by light microscope. In order to evaluate by light microscope, the lower epiderm of leaflets (adaxial surface) coated by a thin layer of nail polish. After a few minutes, a strip of transparent sticky tape was applied on the dried polish. Sticky tapes were peeled from leafleats and along with nail polish mounted on microscopic slides (Banon et al., 2004, Al-Saghir and Porter, 2005, Belhadj et al., 2011). The slides were observed using a light microscope (model Olympus, magnification of $10 \mathrm{x}$ for ocular and a $100 \mathrm{x}$ for objective). Stomata were counted on the middle portion of the leaflet. Evaluation of stomatal dimension (length and width) and trichomes on lower surface of leaf (abaxial surface) were carried out by scanning electron microscope (SEM). SEM provides a more details and high magnification. For examination by SEM, a section of $5 \mathrm{~mm}^{2}$ of leaf surface was fixed on a labelled stub (Belhadj et al., 2007) and then the samples were coated with gold using a sputter coater (SCDOOS, Bal-TEC Co., Switzerland), and analyzed by scanning electron microscope (XL30, Philips Company, the Netherlands). For determination of the width of stomata, both guard cells were measured. All samples were taken from fully expanded leaflets in the same position. In each leaf, five measurements carried out. Data were statistically analysed by SPSS software.

\section{Results}

The results of variance analysis stomata characters are shown in Table 1. Based on results, irrigation, rootstock and their interaction had significant effects on stomata density and stomata length. Effects of irrigation on stomata width was significant but 
rootstock and interaction of irrigation and rootstock had no significant effects on stomata width.

Effect of irrigation on stomata density, length and width is shown in table 2 . The highest stomata number was obtained in severe water stress. The lowest length and width of stomata also were obtained in severe water stress.

The results showed that there were a diversity in traits of stomata in studied rootstocks (Table 3 ). The highest and the lowest stomata density on the abaxial surface was belonged to $P$. mutica $(530.30$ $\mathrm{no} / \mathrm{mm}^{2}$ ) and $P$. vera 'Ghazvini $\left(404.04 \mathrm{no} / \mathrm{mm}^{2}\right.$ ), respectively. The rootstock $P$. mutica had significant difference with other rootstocks. The rootstocks $P$. mutica and $P$. vera 'Ghazvini' had the highest and $P$. vera 'Badami' and $P$. vera 'Sarakhs' the lowest stomata length of stomata. There were found no significant difference in stomata width.
Effects of interaction of irrigation and rootstock are shown in figure 1. Interaction of irrigation and rootstock had significant effects on stomata density and stomata length, while this effect was not significant on stomata width.

The shape of epidermal cells also was different among studied rootstocks (figure 2). In 'Badami' and Ghazvini, the margins of epidermis cells were wavy.

In 'Sarakhs', the margins of almost of epidermal cells were straight and a few cells were wavy. In P. mutica, epidermal cells had irregular shaped but not very much wavy. All rootstocks had anomocytic stomata as shown in figure 2.

In the present study non-glandular trichomes were found on abaxial surface of P.mutica, while in other rootstocks, trichomes were not found (Figure 3). Presence of trichomes in P.mutica is a

Table 1. Analysis of variance of stomata characters of four pistachio rootstocks at three irrigation levels.

\begin{tabular}{lcccc}
\hline & $\begin{array}{c}\text { Freedom } \\
\text { degree }\end{array}$ & $\begin{array}{c}\text { Stomata } \\
\text { Density }\end{array}$ & $\begin{array}{c}\text { Stomata } \\
\text { Length }\end{array}$ & $\begin{array}{c}\text { Stomata } \\
\text { Width }\end{array}$ \\
\hline Irrigation & 2 & $17018.35 * *$ & $11.52 * *$ & $6.802 * *$ \\
Rootstock & 3 & $29905.005 * *$ & $10.57 * *$ & $0.935 \mathrm{~ns}$ \\
Irrigation* Rootstock & 6 & $9578.636 * *$ & $6.56 * *$ & $0.36 \mathrm{~ns}$ \\
\hline
\end{tabular}

$\mathrm{ns}, *$ and $* *$ are non significant, significant at 0.05 and significant at 0.01 , respectively.

Table 2. Effect of irrigation on stomata density, length and width of four pistachio rootstocks.

\begin{tabular}{lccc}
\hline & $\begin{array}{c}\text { Stomata } \\
\text { Density } \\
\left(\mathrm{no} / \mathrm{mm}^{2}\right)\end{array}$ & $\begin{array}{c}\text { Stomata } \\
\text { Length }(\mu)\end{array}$ & $\begin{array}{c}\text { Stomata } \\
\text { Width }(\mu)\end{array}$ \\
\hline $100 \%$ ETc (control) & $460.85 \mathrm{a}$ & $24.45 \mathrm{~b}$ & $14.91 \mathrm{~b}$ \\
$65 \%$ ETc (medium stress) & $407.19 \mathrm{~b}$ & $25.37 \mathrm{a}$ & $16.14 \mathrm{a}$ \\
$30 \%$ ETc (severe stress) & $479.79 \mathrm{a}$ & $23.41 \mathrm{c}$ & $14.77 \mathrm{~b}$ \\
\hline
\end{tabular}

Significant differences within the same column are indicated by different letters $(\mathrm{P}=0.05$, Duncan test).

Table 3. Effect of rootstock on stomata density, length and width

\begin{tabular}{|c|c|c|c|}
\hline Rootstock & $\begin{array}{c}\text { Stomata } \\
\text { Density } \\
\left(\mathrm{no} / \mathrm{mm}^{2}\right)\end{array}$ & $\begin{array}{c}\text { Stomata } \\
\text { Length }(\mu)\end{array}$ & $\begin{array}{r}\text { Stomata } \\
\text { Width }(\mu)\end{array}$ \\
\hline Pistacia mutica & $530.30 \mathrm{a}$ & $25.33 \mathrm{a}$ & $15.19 \mathrm{a}$ \\
\hline P. vera 'Badami', & $450.33 \mathrm{~b}$ & $23.61 \mathrm{~b}$ & $14.85 \mathrm{a}$ \\
\hline P. vera 'Ghazvini & $404.04 \mathrm{c}$ & $25.33 \mathrm{a}$ & $15.55 \mathrm{a}$ \\
\hline P. vera 'Sarakhs' & $412.45 \mathrm{bc}$ & $23.38 \mathrm{~b}$ & $15.50 \mathrm{a}$ \\
\hline
\end{tabular}

Significant differences within the same column are indicated by different letters $(P=0.05$, Duncan test $)$ 

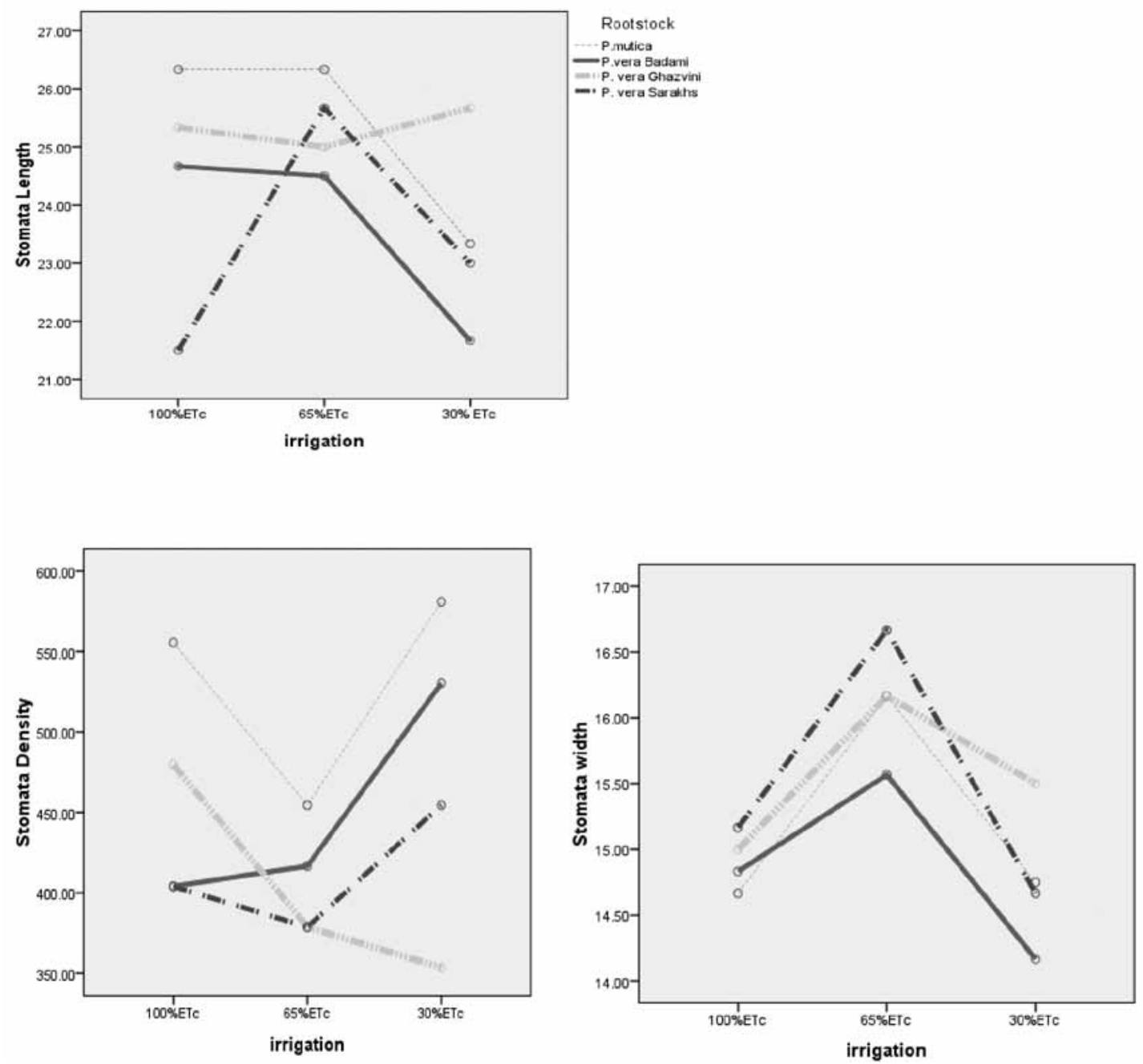

Figure 1. Stomata traits of four pistachio rootstocks under three irrigation levels.

characteristic distinguishable. The Length and width of trichomes were 86.66 and $10 \mu \mathrm{m}$, respectively.

\section{Correlation between stomata traits}

The findings of the present study showed that there were positive correlation $(+0.417)$ between stomata length and stomata width $(\mathrm{P} \leq 0.05)$. It was found a negative correlation $(-0.432)$ between stomata density and stomata width $(\mathrm{P} \leq 0.01)$. There were not found correlation between stomata density and stomata length, while in severe treatment of water stress was observed significant negative correlation between stomata density and stomata length $(-.0 .675)$ at $\mathrm{P} \leq 0.05$. It means that water stress can reduces stomata length and causes this correltions. P. vera 'Ghazvini had the lowest number of stomata but wider stomata.

\section{Discussion}

Stomatal density is a important characteristic and may remarkably affect gas exchanges. Muradoglu and Gundogdu, 2011 showed frequency of stomata in walnut was $273.21 / \mathrm{mm}^{2}$. Çaglar et al. (2004), reported number and length of stomata on the lower surface of walnut leaves were varied between 120 $-217 / \mathrm{mm}^{2}$. Abubakar et al. (2011) reported the highest stomatal length of Moringa genotypes on adaxial surface was $30.8 \mu \mathrm{m}$. Stomata frequency 

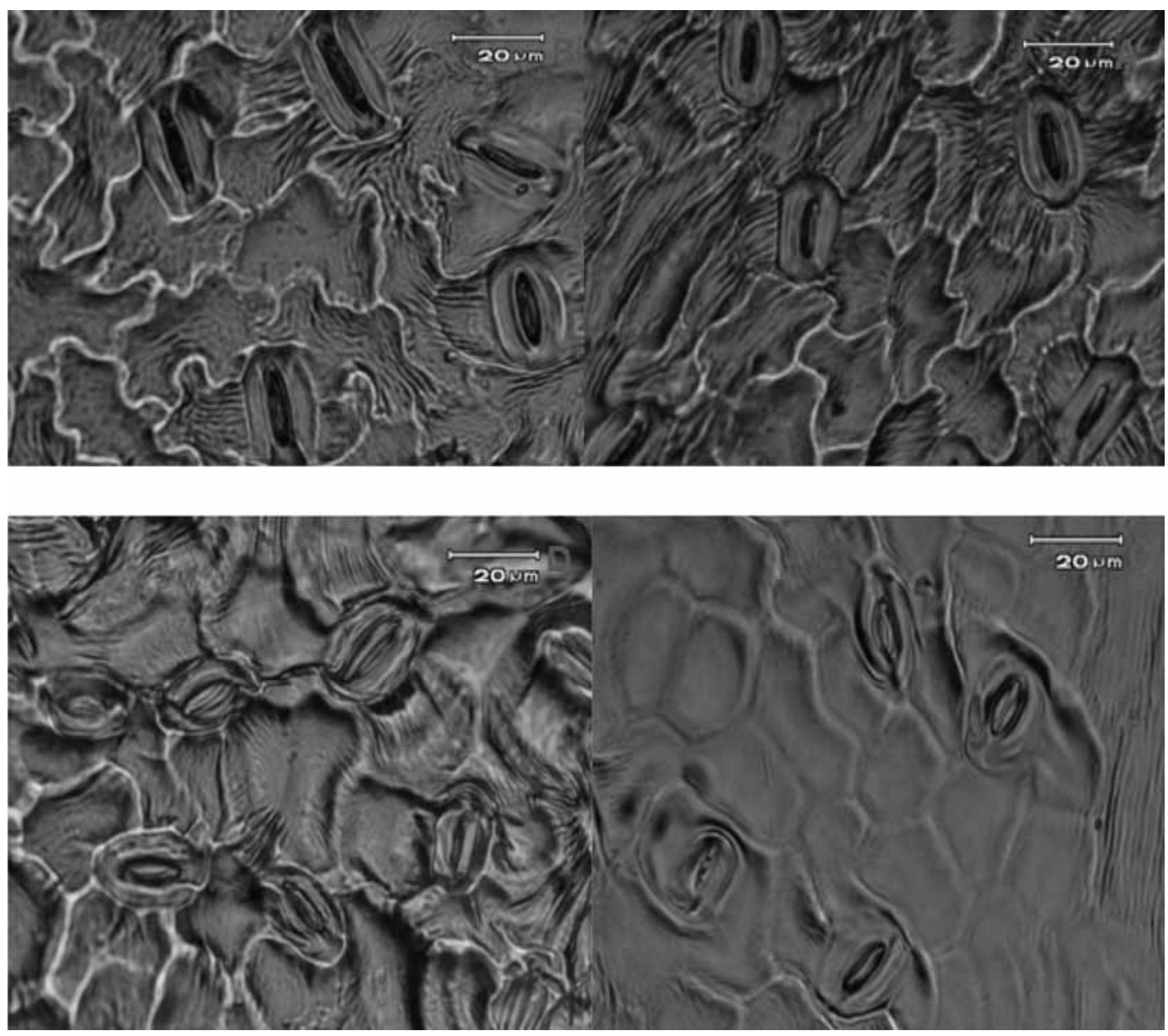

Figure 2. The shape of epidermal cells of pistachio rootstocks.

A: Badami., B: Ghazvini., C: Sarakhs., D: P. mutica.
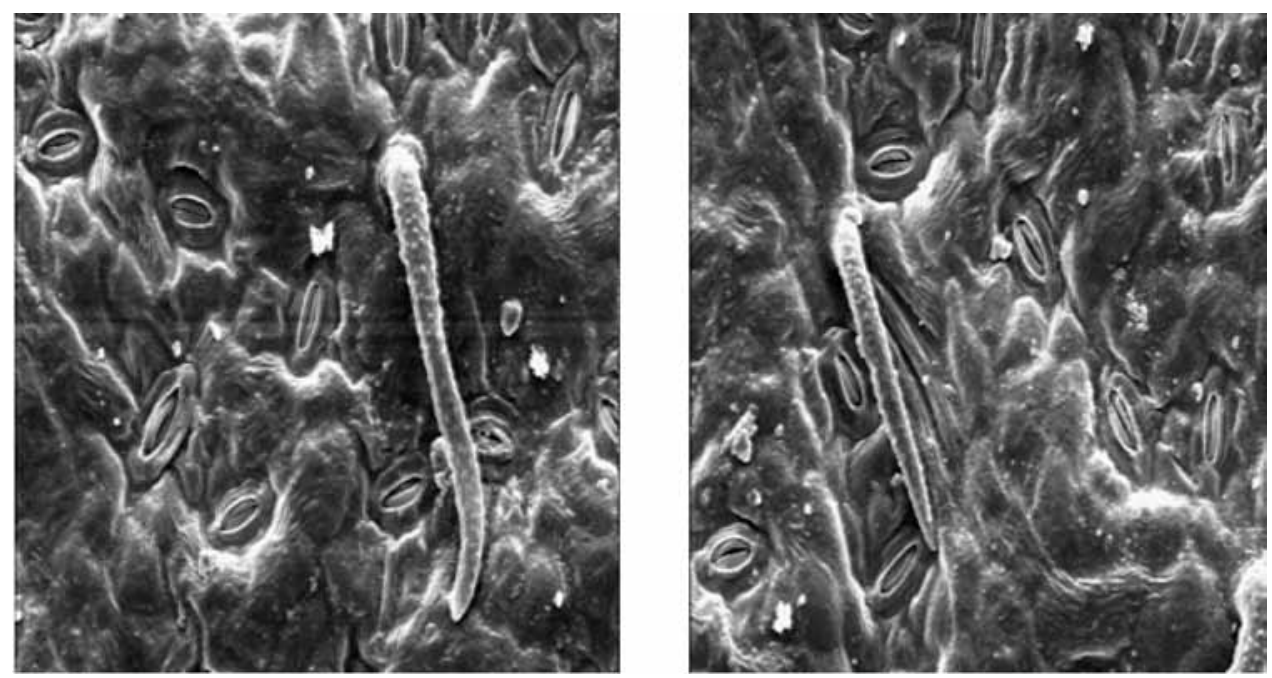

Figure 3. Non-glandular trichomes on abaxial surface of $P$. mutica observed by SEM. 
can be correlated to adaptation process of the trees (Muradoglu and Gundogdu, 2011). It also has reported stomatal density is used as a selection marker for disease-resistance breeding of tabacco (Yang et al., 2004). The higher stomatal density is an indicator for higher transpiration rate, highest metabolism and absorption of mineral and water (Munir et al., 2011). The trichomes found in P. mutica is indicator for presence of drought tolerance mechanism in this rootstock. These trichomes have epidermal origin and prevent from direct sun light, so can prevent from rapid transpiration. Munir et al. (2011) also reported $P$. integerrima had non-glandular trichome only on adaxial surface. In some xerophytic plants stomata are often sunken and covered by trichomes to prevent water loss (Stace, 1965, Fahn, 1967). Ozeker and Misirli (1999) reported there was a negative correlation between the stomatal number and leaf width in pistachio that was according our results. Evaluation of Woo, (2010) on poplar showed a clone with lower stomata density, stomata are larger. They also showed there was negative correlation between stomata number and length in abaxial surface.

Generally stomata are very important in plant physiology. Yang et al., (2004) found positive correlation between stomatal density and WUE, and negative correlation between stomatal aperture (Width/length) and WUE. The stomata control $\mathrm{CO}_{2}$ absorption for photosynthesis and regulate water loss through transpiration, so are important in plant growth and development (Yang et al., 2004).

Epidermal cells affected by many factors like high wind speed and soil moisture content, which can increase cellular turgidity and hence more waviness (Abubakar et al., 2011). In drought conditons, an efficient stomatal apparatus permitting continued assimilation during drought is preferable (Henzell et al., 1976). In dry climates, plants have smaller stomata with less length and width and with a higher stomata density to control transpiration and save more water (Bosabalidis and Kofidis, 2002, Belhadj et al., 2011, Hetherington and Woodward, 2003). Our study showed that rootstocks had variation in the epidermal cell such as stomata size, stomata shapes, epidermal cells and presence or absence of trichomes. The results showed that water stress increased stomatal density of pistachio rootstocks and the highest stomata density were obtained in severe water stress.

These findings can be used for distinguish between the two species or for genetic improvement drought resistance.

\section{Acknowledgement}

Authors are grateful for providing seeds of pistachio rootstocks by the Iran's Pistachio Research Institute, Rafsanjan, Iran.

\section{References}

Abubakar, B.Y.; MuA'zu, S.; Khan, A.U. and Adamu, A.K. 2011 Morpho-anatomical variation in some accessions of Moringa oleifera Lam. from Northern Nigeria. African Journal of Plant Science. 5(12): 742-748.

Al-Saghir, M.G. and Porter, D.M.

2005 Stomatal distribution in pistacia sp.(Anacardiaceae). International Journal of Botany. 1(2): 183-187.

Banon, A.; Fernandez, J.A.; Franco, J.A.; Torrecillas, A.; Alarcon, J.J. and Sanchez- Blanco, M.J.

2004 Effects of water stress and night temperature preconditioning on water relations and morphological and anatomical changes of Lotus creticus plants. Sci. Hort. 101: 333-342.

Belhadj, S.; Derridj, A.; Moriana, A.; Gijon, M.D.C.; Mevy, J.P. and Gauquelin, T.

2011 Comparative analysis of stomatal characters in eight wild atlas pistachio populations (Pistacia atlantica Desf.; Anacardiaceae). International Research Journal of Plant Science. 2(3): 060-069.

Belhadj, S.; Derridj, A.; Aigouy,T.; Gers, C.; Gauquelin, T. and Mevy, J.P.

2007 Comparative morphology of leaf epidermis in eight populations of atlas pistachio (Pistacia atlantica Desf.,
Anacardiaceae). Microscopy research and technique. 70: 837-846.

Bosabalidis, A.M. and Kofidis, G.

2002 Comparative effects of drought stress on leaf anatomy of two olive cultivars. Plant Sci. 163: 375-379.

Çaglar, S.; Sutyemez, M. and Beyazit, S.

2004 Stomatal density in some selected walnut (Juglans regia L.) types (in Turkish with English Abstract). J. Akdeniz Univ. Agric. Fac., 17: 169-174.

Dickison, W.C.

2000 Integrative plant Anatomy. Academic Press, San Diego.

Elfadl, M.A. and Luukkanen, O.

2006 Field studies on the ecological strategies of Prosopis juliflora in dry land ecosystem 1. A leaf gas exchange approach. J. Arid Env. 66: 1-15.

El-Oqlah, A.A.

1996 Biosystematic research on the genus Pistacia in Jordan. In: Padulosi S, Caruso T, Barone E, editors. Taxonomy, distribution, conservation and uses of Pistacia genetic resources (Workshop). Palermo, Italy, June 29-30, 1995. pp. 12-19.

Fahn, A.

1967 Plant anatomy. First edition. Pergamon Press. Exeter. $534 \mathrm{p}$. 
Henzell, R.G.; McCree, K.J.; van Bavel, C.H.M. and Schertz, K.F. 1976 Sorghum genotype variation in stomatal sensitivity of leaf water deficit. Crop Sci., 16: 660-662.

Muradoglu, F. and Gundogdu, M.

2011 Stomata size and frequency in some walnut (Juglans regia) cultivars. International Journal of Agriculture \& Biology 13: 1011-1015.

Hetherington, A.M. and Woodward, F.I.

2003 The role of stomata in sensing and driving environmental change. Nature. 424: 901-908.

Martins, M.B.G. and Zieri, R.

2003 Leaf anatomy of rubber-tree clones. Sci Agric 60:709-713.

Munir, M.; Khan, M.A.; Ahmed, M.; Bano, A.; Ahmed, S.N.; Tariq, K.; Tabassum, S.; Mukhtar, T.; Ambreen, M. and Bashir, S. 2011 Foliar epidermal anatomy of some ethnobotanically important species of wild edible fruits of northern Pakistan. Journal of Medicinal Plants Research. 5(24):5873-5880.

Ozeker, E. and Misirli, A.

1999 A study of stomatal distribution and leaf characteristics in some citrus species and cultivars. 3. Turkish National Horticulture Congress in Ankara, Turkey, 14-17.
Scatena, V.L.; Giulietti, A.M.; Borba, E.L. and van der Berg, C. 2005 Anatomy of Brazilian Eriocaulaceae: correlation with taxonomy and habitat using multivariate analysis. Plant Syst. Evol., 253: 1-22.

Stace, C.A.

1965 Cuticular studies as an aid to plant taxonomy. Bull. Bri. Mus. (Natural History). Bot. 4: 1-78.

Woo, S.Y.

2010 Epidermal leaf characteristics and seasonal changes of net photosynthesis of five Populus. African Journal of Biotechnology. 9(10):1455-1458.

XueJun, D. and XinShi, Z.

2000 Special stomatal distribution in Sabina vulgaris in relation to its survival in a desert environment. Trees. 14: 369-375.

Yang, T.Z.; Zhang, X.Y. and Wang, G.X.

2004 Relationships between stomatal character, photosynthetic character and seed chemical composition in grass pea at different water availabilities. Journal of Agricultural Science. 142: 675-681. 
